\title{
Urgensi Pelatihan Syukur (Gratitude Traning) untuk Meningkatkan Subjective Well-Being "Ibu Muda" dalam Konteks Keluarga
}

\author{
Endang Prastuti \\ Fakultas Pendidikan Psikologi, Universitas Negeri Malang \\ endang.prastuti.fppsi@um.ac.id
}

\begin{abstract}
Building a family life is basically aimed to successfully achieving life satisfaction and happiness, which we use the term subjective well-being. Empirical data shows that family life is a dynamic process of adaptation, therefore events such as problems, stress, pressure and crisis are not determinants of subjective wellbeing, but rather how to improve the ability of individuals to make the intended coping. Gratitude is a form of coping response which is a predictor of subjective well-being. Gratitude can be activated and trained continuously through the process of learning and training throughout life, thus forming the power of transcendence. The research findings show that: gratitude can be done by implementing cognitive emotional regulation strategies, namely (a) refocus on planning, (b) putting into perspective, (c) positive appraisal. In addition, the activation of gratitude can be done through mindfulness by using the strategy $3 \mathrm{~A}$, namely (a) Attention (b) Awareness (c) Acceptance, and activating gratitude with the counting of blessing method. Recommendations for future research: it is necessary to develop a gratitude training model that is proven effective in increasing the subjective well-being of "young" mothers (20-40 years).
\end{abstract}

Keywords: gratitude training; subjective well being; young mother

\begin{abstract}
Abstrak
Membangun kehidupan berkeluarga pada dasarnya bertujuan mencapai kepuasan hidup dan kebahagiaan, diistilahkan dengan subjective well-being. Data empiris menunjukkan bahwa hidup berkeluarga merupakan proses adaptasi yang dinamis, oleh karena itu kejadian-kejadian hidup yang berupa frustrasi, stres, tekanan dan krisis bukan penentu subjective well-being, akan tetapi bagaimana kemampuan individu untuk melakukan koping itu yang terpenting. Rasa syukur merupakan bentuk respon koping yang berperan sebagai prediktor subjective wellbeing. Rasa syukur dapat diaktivasi dan dilatih secara terus menerus melalui proses belajar dan latihan sepanjang hidup, sehingga membentuk character strength transcendence. Temuan penelitian menunjukkan bahwa: rasa syukur dapat dilakukan dengan melakukan strategi regulasi emosi kognitif yaitu (a) refocus on planning, (b) putting into perspective, (c) positive appraisal. Selain itu, aktivasi rasa syukur dapat dilakukan melalui mindfulness dengan menggunakan strategi 3 A yaitu (a) Attention (b) Awareness (c) Acceptance, serta mengaktivasi
\end{abstract}


rasa syukur dengan metode counting of blessing. Rekomendasi untuk penelitian ke depan: perlu dikembangkan gratitude training model yang terbukti efektif untuk meningkatkan subjective well-being ibu "muda" (20-40 tahun).

Kata kunci: pelatihan syukur; subjective well-being; ibu muda.

\section{Pendahuluan}

Paradigma psikologi positif merupakan kajian ilmiah memfokuskan pada kualitas personal, sebagai upaya meningkatkan kehidupan yang baik ditandai dengan kebahagiaan, kesehatan fisik dan mental (Baumgardner \& Crothers, 2010). Tiga pilar psikologi positif yaitu: (a) pengalaman subjektif yang positif seperti: kebahagiaan, ketenangan dan harapan, (b) karakteristik positif yaitu kekuatan personal dan kebaikan (c) komunitas positif yang memberi kontribusi pada kesehatan dan kebahagiaan individu (Seligman, dkk., 2005; 2010).

Keluarga merupakan bentuk kecil dari komunitas, dibangun dengan tujuan mencapai kebahagiaan atau kesejahteraan subjektif, namun demikian ditengarai peristiwa hidup berupa: frustrasi, stres, tekanan dan krisis dapat mempengaruhi kebahagiaan di dalam keluarga. Merujuk pada pendekatan psikologi positif, menjelaskan bahwa salah satu pilar mencapai kebahagiaan yang sejati adalah ketika individu dapat merasakan hidup yang bermakna yakni kebahagiaan yang melampaui kepentingan pribadi, lebih dalam dan bertahan lama (Seligman, dkk, 2006, dikutip Baumgardner \& Crothers, 2010), yang dapat diperoleh ketika seseorang dapat menemukan kebahagiaan dalam keluarga.

Telaah literatur membuktikan kekuatan karakter (character strength) merupakan prediktor kesejahteraan subjectif (subjective well-being). Rasa syukur (gratitude), merupakan character strength transcendence, telah terbukti dalam berbagai penelitian merupakan kunci kesejahteraan subjektif pada sampel yang beragam, termasuk sampel ibu "muda" usia 20-40 tahun (Prastuti, Tairas \& Hartini, 2019). Rasa syukur dapat diartikan sebagai akumulasi perasaan positif, seperti perasaan terimakasih, terberkahi, dicintai (Hlava \& Elfers, 2014). The Broden-Built Theory (Fredricson, 2002), menyatakan bahwa perasaan positif akan mampu membangun psychological resources yakni kebahagiaan hidup dalam 
keluarga. Sementara itu, ditengarai periode dewasa muda, pada responden ibu mengalami problematik subjective well-being, oleh karena itu aktivasi rasa syukur menjadi penting dan urgen. Rasa syukur bisa dipandang sebagai respon koping, trait dan character strength transcendence (Peterson \& Seligman, 2004), dapat dipelajari melalui proses belajar dan pelatihan terstruktur.

Merujuk pada telaah literatur, tulisan ini akan mengulas hal-hal berikut (1) Subjective well-being dalam konteks keluarga 2) Kebahagiaan keluarga ditinjau dari teori adaptasi (3) Rasa syukur kunci kebahagiaan dalam keluarga (3) Urgensi pelatihan syukur (gratitude training) pada ibu "muda" (4) Materi dan strategi pelatihan syukur (gratitude training) yang direkomendasikan.

\section{Telaah Literatur}

\section{Subjective Well Being Dalam Konteks Keluarga}

Keluarga sebagai sistem merupakan satu kesatuan yang terdiri dari komponen yang berinteraksi untuk mencapai suatu tujuan tertentu. Pendekatan sistem memandang bahwa lazimnya keluarga inti terdiri dari ayah, ibu dan anak yang saling berinteraksi untuk mencapai kebahagiaan, sebagai tujuan akhir. Perspektif psikologi keluarga juga menjelaskan fungsi keluarga antara lain: (a) mendidik dan sosialisasi anak, (b) menciptakan lingkungan yang mendukung, (c) memenuhi kebutuhan emosional. Berbagai teori tentang keluarga, menjelaskan bahwa keluarga merupakan crucial environment bagi setiap orang, terjadi saling hubungan antar bagian, serta terjadi pertukaran secara timbal balik serta berpeluang mengalami konflik, yang perlu dikelola menjadi keadaan yang harmoni (Bray \& Stanton, 2009).

Perspektif perkembangan menyebutkan bahwa menikah dan berkeluarga merupakan tugas perkembangan pada fase dewasa. Tujuan akhir menikah dan berkeluarga adalah mencapai kehidupan keluarga yang bahagia dan sejahtera. Hal ini relevan dengan karakteristik perkembangan aspek kognitif fase dewasa yakni responsibility stage artinya secara kognitif periode ini lebih fokus pada pemecahan problem hidup terkait tanggung jawab dalam karir maupun keluarga. Ditinjau dari aspek psiko-sosial, periode dewasa ditandai dengan kedekatan 
(intimacy) yang matang dengan orang lain, ditunjukkan dengan kemauan berbagi secara timbal balik, melibatkan pengurbanan, kompromi serta komitmen dalam hubungan yang saling memuaskan dengan pasangan, dibingkai dalam hubungan cinta serta kepedulian dalam melaksanakan tugas pengasuhan anak (Aiken, 2002; Papalia \& Olds, 1986).

Hasil penelitian terhadap ibu "muda" (usia 20-40), menunjukkan bahwa definisi kesejahteraan subjektif atau diistilahkan dalam bahasa sehari-hari dengan “ kebahagiaan” adalah terkait dengan konteks keluarga (subjective well-being in family domain) khususnya interaksi dengan pasangan dan anak. (Prastuti, 2016). Namun demikian, ditemukan fakta empiris yang menarik bahwa menurut persepsi responden, keluarga merupakan sumber kebahagiaan urutan pertama (Prastuti, 2016), sekaligus menjadi sumber ketidakpuasan (Eggleston, dkk., 2001; Prastuti, 2016; 2018). Ditinjau dari periode perkembangan, membuktikan bahwa periode dewasa "muda" (20-40 tahun), mengindikasikan problematik kesejahteraan subjektif mencapai puncaknya, meski dengan rentang usia yang sedikit beragam. Data penelitian menunjukkan titik kebahagiaan terendah terjadi pada usia 30-40 tahun (Mroczek \& Kolarz, 1998, dalam Santrock, 2011), transisi umur 30-an usia 28-33 tahun (Levinson dalam Papalia \& Olds, 1986; Aiken, 2002), ditandai dengan krisis perkembangan dengan problem pernikahan yang tinggi dan tingkat perceraian mencapai puncaknya.

Subjective well-being ditandai adanya tingginya kepuasan hidup dan perasaan positif dan rendahnya perasaan negatif seperti: stres, tertekan, cemas, depresi. Penelitian pada responden ibu melaporkan bahwa terkait dengan interaksi dengan anak, ibu kurang bahagia, lebih tinggi stres dan kelelahannya ketika bersama anak (Musick, dkk., 2014), demikian halnya pada ibu bekerja, ditandai dengan depresi dan kecemasan yang tinggi (Repetti \& Wood, 1997), refleksi adanya subjective well-being yang rendah. Konteks budaya di Indonesia memperkuat munculnya fenomena ini, karena dunia istri adalah rumah tangga dan pengasuhan anak, sekalipun istri bekerja tetap ada tuntutan terhadap kewajiban rumah tangga, mengasuh anak (Trisetiono, 2011). 
Kesejahteraan subjektif (subjective well-being) dalam keluarga, utamanya dimensi interaksi dengan pasangan, ditandai dengan kepuasan pada aspek perkawinan yakni ketika pasangan mendapatkan secara timbal balik dan seimbang semua dimensi suatu hubungan (Cavanaugh \& Blanchard-Field, 2010), namun demikian kepuasan pernikahan terjadi di awal pernikahan kemudian terus turun hingga anak meninggalkan rumah, selanjutnya baru muncul kepuasan pernikahan pada periode berikutnya (Hansen, dkk., 2007 dalam Cavanaugh \& Blancard-Field, 2010).

Berdasarkan uraian di atas dapat disimpulkan bahwa periode usia dewasa muda (20-40 tahun), ditandai adanya problematik subjective well-being dalam konteks keluarga, terutama terkait interaksinya dengan pasangan dan pengasuhan anak. Uniknya problematik kesejahteraan subjektif tersebut menonjol dialami oleh wanita baik sebagai istri dan ibu. Ulasan berikut fokus mengkaji teori adaptasi, yang merupakan komponen sentral teori modern subjective well-being (Diener, dkk., 1999) dalam menjelaskan psikodinamika dan rekomendasi terhadap solusi terkait problematik empiris tersebut.

\section{Kebahagiaan Keluarga: Ditinjau dari Teori Adaptasi}

Awalnya teori adaptasi Hedonic treadmill model dalam menjelaskan kebahagiaan, menegaskan bahwa kejadian hidup baik atau buruk secara temporer mempengaruhi kebahagiaan, tetapi individu dengan cepat beradaptasi ke dalam kondisi hedonic dan netral (Brickman \& Campbell, dikutip Diener, dkk., 2006). Revisi terhadap Hedonic treadmill model, bahwa terdapat perbedaan individual dalam melakukan adaptasi, salah satunya ditentukan oleh perbedaan dalam memberikan reaksi terhadap kejadian eksternal (Diener, dkk., 2006). Mekanisme yang menentukan adaptasi terhadap kejadian hidup lebih menekankan peran aktif individu (Diener, dkk., 1999).

Merujuk pada teori adaptasi tentang subjective well-being, maka dapat disimpulkan bahwa kondisi eksternal atau kejadian hidup tidak berdampak langsung terhadap kebahagiaan seseorang, akan tetapi bagaimana individu melakukan respon koping secara positif terhadap seluruh kejadian hidup, merupakan kunci kebahagian dalam keluarga. Hal ini sejalan dengan teori 
vulnerability-stress-adaptation of mariage bahwa kualitas pernikahan sebagai proses dinamis, hasil dari kemampuan pasangan untuk mengatasi kejadian hidup yang penuh stres (Karney \& Bradbury, 1995 dalam Cavanaugh \& Blancard-Field, 2010).

Di awal-awal hidup berkeluarga biasanya pasangan membawa impian masing masing, namun realitas seringkali berbeda dengan impian. Hasil penelitian terhadap pasangan suami istri, dengan usia pernikahan di bawah 10 tahun menunjukkan hasil temuan yang menarik, di mana pola penyesuaian perkawinan umumnya mengikuti tahap berikut: (1) fase bulan madu, merupakan fase paling indah, karena masing-masing berusaha membahagiakan pasangannya, dan meminimalkan perbedaan, (2) fase pengenalan realitas: terkait dengan hal-hal yang memerlukan proses adaptasi, bersumber pada kebiasaan-kebiasaan pasangan, (3) fase kritis perkawinan, merupakan fase yang paling rawan dan semakin meruncing ketika ada keterlibatan keluarga, dan lazimnya masalah seksual dapat menjadi pemicu, (4) fase menerima kenyataan, pasangan menjalani perkawinan dengan cara yang disepakati, (5) fase kebahagiaan sejati, ketika perbedaan tidak menjadi penghalang untuk mencapai tujuan perkawinan yaitu kebahagiaan (Anjani \& Suryanto, 2006).

Hasil penelitian diperkuat dengan temuan penelitian pada ibu "muda" usia 20-40 tahun, menunjukkan bahwa subjective well-being di level terendah berada pada usia perikahan 1-4 tahun pertama (Prastuti, 2016). Ditinjau dari perspektif perkembangan, usia dewasa muda mengindikasikan adanya fenomena krisis perkembangan. Hal ini ditunjukkan dengan hasil penelitian kualitatif dilakukan terhadap 50 subjek laki-laki dan perempuan usia 25-35 tahun menemukan adanya krisis perkembangan yang meliputi: (1) fase locked-in, ditandai dengan struktur hidup yang belum realistis, pola karir yang penuh tekanan dan tidak memuaskan, menimbulkan kondisi lepas kontrol dan penuh stres, (2) fase time-out, merupakan periode yang diwarnai dengan emosi yang kuat seperti perasaan bersalah, kesedihan, kecemasan, muncul dorongan untuk berubah atau melarikan diri, (3) exploration, (4) rebuilding (Robinson, dkk., 2013). Berdasarkan temuan ini menguatkan fakta bahwa krisis perkembangan usia 25-35 tahun, merupakan fase 
"titik bahaya" yakni ketika berada pada fase locked-in dan time out, yang mengindikasikan ketidakbahagiaan, ditandai dengan munculnya berbagai emosi negatif seperti stres, tertekan, perasaan bersalah, kecemasan dan kesedihan.

Merujuk pada kerangka teoritik subjective well being (Diener, dkk., 1999), problematik keluarga ditandai dengan problematik subjective well-being dimensi kognitif (life satisfaction), yakni penilaian seseorang mengenai kehidupannya dalam konteks keluarga dibandingkan dengan standar baik standar diri sendiri dan orang lain. Aspek kepuasan hidup dalam keluarga meliputi: komunikasi, resolusi konflik, waktu luang, keuangan, hubungan seksual, kesetaraan peran, orientasi agama, kepribadian, keluarga besar dan pengasuhan (Fower \& Olson, 1993; Brooks, 2011).

Kepuasan hidup dalam konteks keluarga pada responden ibu usia "muda" (20-40 tahun), menghasilkan temuan yang menarik, yaitu kepuasan hidup domain keluarga yang paling rendah adalah pada aspek pengasuhan anak. Artinya bahwa meskipun sebagian besar responden berpendidikan tinggi dan pendapatan keluarga yang cukup memadai, aspek pengasuhan masih menjadi sumber ketidakpuasan bagi ibu "muda". Responden dibagi di dalam tiga kelompok usia yakni (a) usia 22-28 tahun (b) usia 29-33 tahun (c) 34-40 tahun. Skor kepuasan hidup dalam domain keluarga bergerak diantara skor terendah 1.00, hingga skor tertinggi 5.00. Hasil penelitian menunjukkan pola yang unik: pada usia 22-28 tahun kepuasan hidup dalam ranah keluarga cukup tinggi $(3,92)$, kemudian di usia 29-33 tahun mengalami penurunan (3,84), kemudian mulai usia 34-40 tahun mulai naik lagi $(3,91)$. Berdasarkan data ini dapat disimpulkan bahwa pola kepuasan hidup dalam domain keluarga ditinjau dari usia membentuk huruf "U”, maknanya titik terendah kepuasan hidup dalam keluarga berada di usia 29-33 tahun. Hal ini berarti pada usia transisi usia 30 an, diduga merupakan critical period pada aspek kepuasan hidup dalam keluarga (Prastuti, Tairas \& Hartini, 2019).

\section{Rasa Syukur: Kunci Kebahagiaan dalam Keluarga}

Teori vulnerability-stress-adaptation of mariage menjelaskan bahwa kualitas pernikahan sebagai proses dinamis, hasil dari kemampuan pasangan untuk mengatasi kejadian hidup yang penuh stres (Karney \& Bradbury, 1995 
dalam Cavanaugh \& Blancard-Field, 2010). Hal ini berarti, kunci kebahgiaan adalah terletak pada bagaimana cara seseorang mengatasi stres atau disebut dengan coping stress. Rasa syukur selain dipandang sebagai perasaan positif, trait maupun kekuatan karakter, juga berperan sebagai respon koping (coping respon), oleh karena itu bila rasa syukur dapat diaktivasi dalam kehidupan sehari-hari melalui proses belajar sepanjang hidup maka dapat berperan sebagai "kunci' mengaktivasi kebahagiaan di dalam keluarga.

Rasa syukur didefinisikan sebagai rasa terimakasih dan rasa senang ketika menerima hadiah, karunia atau pemberian, baik itu yang nyata, diperoleh dari orang lain atau momen yang memberi kedamaian (Emmons, 2004). Konsep rasa syukur pada level disposisi dipandang sebagai konsep yang luas menekankan pada "orientasi hidup" dengan memperhatikan dan menghargai hal-hal yang positif dalam hidup (Emmons \& Stern, 2013). Hal ini berarti bahwa rasa syukur tidak hanya bermakna menghargai bantuan secara interpersonal, namun menekankan pada persepsi terhadap "segala sesuatu" yang berharga dalam hidup (Wood, dkk., 2010).

Hasil penelitian telah membuktikan aktivasi rasa syukur berperan penting untuk meningkatkan subjective well-being pada subjek beragam (Emmons \& McCulhough, 2003; Martinez, dkk., 2010; review Wood, dkk., 2010, Tofangchi, 2013; Froh, dkk., 2009; Froh, dkk., 2011; Datu, 2014, Safaria, 2014). Hasil penelitian memperkuat hasil temuan sebelumya bahwa rasa syukur merupakan prediktor yang berpengaruh langsung terhadap subjective well-being pada ibu "muda" (Prastuti, Tairas \& Hartini, 2019). Implikasi dari temuan ini adalah rasa syukur meupakan kunci kebahagiaan hidup dalam keluarga, maknanya adalah dalam kondisi apapun, sesungguhnya setiap individu dapat memilih untuk merasakan subjective well-being atau kebahagiaan hidup dalam berkeluarga, dengan mengaktivasi rasa syukur secara terus menerus apapun peristiwa hidup yang dialami.

Bagaimana mekanisme rasa syukur berperan terhadap kebahagiaan dalam keluarga? Hal ini dijelaskan dengan broaden built theory bahwa emosi positif akan memperluas (broaden) kecenderungan dalam berpikir dan perilaku, serta 
membangun (build) sumber-sumber personal, seperti: (a) physical resources, (b) psychological resources, (c) intellectual resources, (d) social resources (Fredrickson, 2002; 2003; 2004). Relevan dengan teori ini, rasa syukur merupakan bentuk perasaan positif, dimana ketika seseorang mengalami pengalaman syukur memunculkan berbagai perasaan positif, seperti rasa terimakasih, rasa terberkahi, rasa kagum dan cinta (Hlava \& Elfers, 2014), oleh karena itu perasaan positif ini akan mampu membangun (build) sumber-sumber psikologis, termasuk kepuasan dan kebahagiaan hidup dalam keluarga.

Hasil penelitian mengenai model subjective well-being "ibu muda" (20-40 tahun) memperkuat bukti empiris bahwa pengaruh regulasi emosi dan mindfulness terhadap subjective well-being, dimediasi oleh peran rasa syukur, artinya bahwa rasa syukur merupakan faktor yang berperan penting dan berpengaruh langsung terhadap subjective well-being. Merujuk pada hasil temuan ini, implikasinya adalah: mengaktivasi rasa syukur merupakan cara paling efektif untuk meningkatkan kebahagian hidup dalam keluarga (Prastuti, Tairas \& Hartini, 2019).

\section{Urgensi Pelatihan Syukur (Gratitude Training)}

Kejadian hidup yang muncul dalam keluarga (frustrasi, stres, tekanan dan krisis) tidak secara langsung menyebabkan emosi negatif, tetapi peran respon koping positif melalui syukur berperan sebagai mediator. Respon koping dapat dilakukan dengan memaknai secara positif kejadian-kejadian hidup yang bermuatan negatif, dengan strategi yang dapat dipilih, antara lain strategi positive reappraisal dan positive meaning (Tugade \& Fredrickson, 2007). Selain itu, respon koping dapat dilakukan dengan mengaktivasi rasa syukur dengan memaknai bahwa "semua hal" dalam hidup yang berarti dan bernilai (Wood, dkk., 2007).

Ketika menghadapi problematik dalam keluarga, kemudian individu dapat mengenali bahwa seluruh kejadian hidup, sejatinya adalah "pemberian yang bernilai”, maka syukur bisa diaktivasi, sehingga memungkinkan muncul perasaan senang, dicintai, terberkahi dan rasa terimakasih (Hlava \& Elfers 2014). Dengan mengenali dan menyadari bahwa seluruh kejadian hidup, apakah bermuatan 
"positif atau negatif" adalah "gift" (pemberian, karunia, anugerah), maka dapat berdampak terhadap kebahagiaan seseorang.

Hasil penelitian membuktikan rasa syukur merupakan prediktor kuat dan berpengaruh langsung terhadap subjective well-being (Prastuti, Tairas \& Hartini, 2019). Maknanya adalah adalah rasa syukur merupakan kunci kebahagiaan seseorang dalam hidup berkeluarga. Apapapun kejadian hidup yang dialami, maka seseorang dapat merasakan bahagia ditandai dengan respon emosi positif seperti suka cita, senang, bangga, puas, karena perasaan positif tersebut yang dipilih oleh individu. Artinya kebahagiaan adalah sebuah pilihan. Hal ini diperkuat dengan adanya kesadaran bahwa tujuan hidup sesungguhnya adalah merasakan kebahagiaan bukan mengejar kebahagiaan, oleh karena itu hal yang terpenting adalah terus-menerus mengaktivasi rasa syukur terhadap kehidupan yang telah diberikan Tuhan dari waktu ke waktu, tanpa berkeluh kesah dan mengeluh.

Apakah rasa syukur dapat dipelajari dan dilatihkan? Konsep rasa syukur bermakna respon koping, sifat, kebajikan dan kekuatan karakter. Ketika individu dihadapkan dengan kondisi eksternal, yang memberi signal emosi misalnya ketika meliahat anaknya berberilaku yang tidak diharapkan, biasanya akan memunculkan emosi marah. Dalam kondisi seperti ini, seseorang diharapkan mampu mengaktivasi rasa syukur sebagai respon koping. Apabila seorang dapat melakukan respon koping, maka lama kelamaan respon yang terpola akan membentuk kebiasaan. Bila kebiasaan yang sudah dipelajari berulang muncul dalam berbagai situasi, lama kelamaan membentuk sifat, sebagai inti kepribadian. Sifat yang positif yang terus konsisten dilakukan dalam berbagai momen hidup, muara akhirnya adalah akan membentuk kekuatan karakter (character strength).

Telaah literatur menyimpulkan bahwa rasa syukur merupakan koping respon, kebiasaan, sifat dan kekuatan karakter yang dapat diasah dan diaktivasi dari momen ke momen. Proses pembelajaran syukur dimulai dari melakukan respon koping hingga membentuk kekuatan karakter. Ketika proses belajar terus menerus berlangsung maka akan menjadi otomatis. Artinya ketika seseorang menghadapi kejadian hidup apapun, bahkan yang tidak bisa diprediksi termasuk 
kehilangan pasangan hidup, memiliki anak ABK (misalnya), maka kemampuan ini akan tetap dapat berperan untuk strategi koping positif.

Merujuk pada uraian di atas maka dapat disimpulkan bahwa rasa syukur dapat dipelajari melalui proses belajar dan latihan (training) sepanjang hidup dalam kehidupan riel setiap pribadi. Pelatihan aktivasi rasa syukur dapat dilakukan melalui pendekatan pembelajaran secara terstruktur dalam "seting kelas", kemudian selanjutnya dapat dilakukan alih belajar (transfer of learning) dalam konteks kehidupan riel sehari-hari.

\section{Materi dan Strategi Pelatihan Syukur (Gratitude Training)}

Berbasisis temuan penelitian sebelumnya (Prastuti, Tairas \& Hartini, 2019), maka rasa syukur hanya mungkin diaktivasi melalui dua 'pintu gerbang' yaitu "pintu regulasi emosi" dan "pintu mindfulness". Materi pelatihan rasa syukur yang direkomendasikan penulis untuk dikembangkan terdiri dari (1) materi aktivasi regulasi emosi dengan berbagai strategi (2) materi aktivasi mindfulness dengan berbagai strategi (3) materi aktivasi rasa syukur dengan berbagai strategi.

Berikut akan diuraikan aktivasi rasa syukur dengan regulasi emosi kognitif yaitu: (1) refocus on planning, (2) putting into perspective, (3) positive appraisal, serta aktivasi rasa syukur melalui strategi mindfulness (1) attention \& present focus (2) awareness (3) acceptance, disingkat dengan akronim strategi 3A, serta aktivasi rasa syukur dengan strategi menghitung karunia (counting of blessing). Uraian masing-masing strategi merujuk pada buku: Rasa Syukur Kunci Kebahagiaan Hidup dalam Keluarga (Prastuti, 2019), dijelaskan secara ringkas pada bahasan berikut:

\section{Strategi refocus on planning}

Mengaktivasi regulasi emosi secara kognitif menggunakan refocus on planing, yakni berpikir mengenai langkah yang diambil untuk menghadapi suatu kejadian. Ilustrasi kasus: ketika ibu menyaksikan ananda bermain-main kotor, maka akan memicu emosi negatif pada ibu dengan emosi marah dengan intensitas tinggi. Oleh karena itu, emosi negatif perlu dilakukan netralisasi dengan melakukan regulasi emosi melibatkan strategi kognitif dengan cara berpikir untuk mengambil langkah solusi. Merujuk pada kasus tersebut, sebaiknya orangtua 
berpikir bahwa anak perlu dialihkan untuk bermain-main yang lebih positif, misalnya bermain lego, bermain boneka, bermain balok di ruang bermain. Ketika strategi ini diterapkan maka akan menetralisir emosi ibu yang semula marah dan jengkel menjadi lebih netral dan tenang.

\section{Strategi putting into perspective}

Mengaktivasi regulasi emosi secara kognitif menggunakan putting into perspective yakni berpikir mengenai kejadian dibandingkan dengan kejadian lain. Untuk memudahkan menerapkan strategi ini bisa diilustrasikan seperti contoh kasus berikut: ketika ibu menyaksikan ananda bermain-main kotor, yang memicu emosi negatif pada ibu, seperti jengkel dan marah, maka emosi negatif perlu dinetralkan dengan melakukan regulasi emosi kognitif dengan cara berpikir mengenai kejadian dibandingkan dengan kejadian lain. Merujuk kasus tersebut sebaiknya ibu berpikir bahwa: ketika anak bermain-main "kotor-kotor", sesungguhnya masih jauh lebih baik, dibandingkan ketika anak bermain "pedangpedangan", yang berpeluang melukai anak yang lain. Bila strategi regulasi emosi dapat diterapkan, akan menetralisir emosi ibu yang semula negatif (emosi marah dan jengkel) menjadi lebih netral dan tenang.

\section{Strategi positive reappraisal}

Mengaktivasi regulasi emosi positive reappraisal yakni berpikir dengan memberi makna positif suatu kejadian. Untuk memudahkan menerapkan strategi ini diilustrasikan seperti contoh kasus berikut: ketika orangtua menyaksikan anaknya bermain-main kotor-kotor, yang dapat memicu emosi negatif (emosi marah), maka emosi negatif perlu dikendalikan dan dinetralisir dengan melakukan regulasi emosi kognitif dengan berpikir positif mengenai kejadian. Misalnya pada kasus tersebut orangtua berpikir bahwa ketika anak bermain-main "kotor-kotor", sebenarnya memberi manfaat positif, karena anak berkesempatan mengeksplorasi lingkungan dan dapat mengembangkan kreativitas. Strategi regulasi emosi kognitif positive reappraisal ini akan menetralisir emosi yang semula memiliki intensitas yang kuat (marah dan jengkel) berubah ke arah netral. 


\section{Strategi attention \& present focus}

Dalam kehidupan sehari-hari sebaiknya membiasakan diri untuk fokus pada momen saat ini, bukan fokus pada kejadian yang sudah berlalu yang tidak pernah kembali, atau fokus pada yang akan datang, yang belum hadir. Ketika seseorang fokus pada kejadian yang lalu dan yang akan datang maka akan mengurangi kesadaran di momen saat ini. Misalnya ketika seorang ibu hari ini memasak maka sebaiknya ibu fokus terhadap bahan-bahan yang akan dimasak, menikmati proses memasak, bukan memikirkan di luar yang sedang dikerjakan, begitu juga ketika ibu mengasuh anak, fokus dengan aktivitas tersebut secara penuh, dengan demikian ibu dapat bercengkrama dengan anak dengan perhatian dan kesadaran penuh, tidak terdistraksi dengan hal-hal lain. Inti dari strategi ini adalah untuk mengaktivasi kesadaran dengan fokus terhadap momen saat ini yang sedang dihadapi, menjauhi distraksi atau alih fokus ke peristiwa yang telah terjadi dengan merenungi atau membayangkan peristiwa yang akan terjadi ke depan, yang belum tentu terjadi.

\section{Strategi awareness}

Seseorang sulit menyadari apa yang dilihat dan didengar, bila tidak memperhatikan objek/stimulus yang dilihat dan didengar tersebut. Bila seorang mampu mengamati semua peristiwa hidup dengan fokus maka akan mengaktivasi kesadaran. Sebagai contoh: ketika orangtua mengamati dengan seksama perilaku anaknya menolak makan dengan menu sayur sawi, maka orangtua baru menyadari, bahwa ternyata sayur sawi yang dimasak terlalu asin dan sedikit pahit sehingga anak menolak makan. Latihan aktivasi kesadaran ini dapat dilakukan terus-menerus hingga menjadi respon otomatis, yaitu menyadari secara penuh seluruh peristiwa yang dialami dari momen ke momen.

\section{Strategi acceptance}

Ketika seorang ibu mengamati dan menyaksikan suatu peristiwa, misalnya anaknya yang berusia 4 tahun mencoret-coret tembok rumah, lazimya muncul respon otomatis marah dan jengkel, dengan melakukan proses penilaian terhadap perilaku tersebut sebagai sesuatu yang "baik dan buruk". Strategi untuk melatih "acceptance", adalah dengan tidak melakukan penilaian atau membandingkan 
dengan standar diri dan orang lain atau standar yang diidealkan. Jadi, strategi acceptance pada kasus tersebut dilakukan dengan sikap "menerima" apapun kejadian hidup apa adanya, tanpa menilai sebagai "baik atau buruk".

\section{Strategi menghitung karunia (Counting of blessing)}

Salah satu strategi mengaktivasi rasa syukur adalah dengan menggunakan metode menghitung karunia (counting of blessing methods). Metode ini awalnya dipelopori oleh Emmons \& McCullough (2003), dengan menggunakan penelitian eksprerimen untuk menguji pengaruh syukur terhadap subjective well-being. Kelompok eksperimen diminta untuk menghitung peristiwa peristiwa positif yang terjadi dalam satu minggu, sebaliknya kelompok kontrol (kelompok keluh kesah) diminta menghitung peristiwa negatif yang dikeluhkan dalam satu minggu.

Terinspirasi dari metode ini aktivasi rasa syukur dapat dilakukan dengan menghitung dan mengidentifikasi karunia atau anugerah yang telah diterima, di seluruh dimensi kehidupan: misalnya: kondisi fisik, psikologis, ruhani, kondisi keluarga, dan aspek yang lain sebagai "karunia dan anugerah" yang layak disyukuri. Diharapkan dari metode "menghitung karunia", akan dapat mengundang emosi positif seperti rasa senang, rasa dicintai dan rasa terimakasih, sehingga membangun "kesadaran" bahwa ternyata telah banyak karunia yang diterima di setiap detik waktu. Dampak dari aktivasi rasa syukur, akan mengundang perasaan positif, yang terakumulasi dalam satu kondisi yang paripurna yakni kesejahteraan subjektif (subjective well-being).

\section{Kesimpulan}

Menikah dan membangun kehidupan berkeluarga, merupakan salah satu tugas perkembangan usia dewasa, dengan tujuan dapat mencapai kepuasan dan kebahagiaan, diistilahkan dengan subjective well-being. Faktanya hidup berkeluarga merupakan proses adaptasi yang dinamis, oleh karena itu, bukan kejadian-kejadian hidup yang terus berubah yang menjadi sumber ketidakbahgiaan, namun bagaimana kesediaan individu untuk melakukan respon koping itu yang terpenting. Rasa syukur merupakan bentuk respon koping yang perlu diaktivasi, karena merupakan prediktor kebahagiaan ibu dalam keluarga. 
Rasa syukur merupakan salah satu bentuk positive affecct yang berpengaruh langsung terhadap subjective well being. Dengan demikian, aktivasi rasa syukur menjadi kunci bagi ibu" muda" khususnya untuk mencapai kebahagiaan hidup dalam konteks keluarga.

Rasa syukur dapat diaktivasi dan dilatih secara terus menerus melalui proses belajar dan latihan sepanjang hidup, sehingga mampu membentuk kekuatan karakter transenden. Proses belajar bisa dimulai dengan mengaktivasi syukur sebagai respon koping. Respon koping ketika dilakukan dalam berbagai kondisi akan memunculkan kebiasaan. Ketika kebiasaan semakin berdampak luas dalam berbagai situasi dan kondisi maka akan membentuk trait, sebagai inti kepribadian. Selanjutnya, trait yang bermuatan positif, pada akhirnya akan membentuk character strength. Rasa syukur yang sudah menjadi character strength maka karakter ini akan terus melekat dalam diri hingga ke sel-sel DNA.

Pengembangan pelatihan syukur secara komprehensif, sejauh ini belum dilakukan. Temuan penelitian membuktikan bahwa rasa syukur dapat dilakukan dengan pelatihan menggunakan strategi regulasi emosi secara kognitif yaitu (1) refocus on planning, (2) putting into perspective, (3) positive appraisal. Selain itu, aktivasi rasa syukur dapat dilakukan melalui mindfulness dengan menggunakan strategi 3 A yaitu (1) Attention (2) Awareness (3) Acceptance. Pelatihan aktivasi rasa syukur urgen untuk diberikan kepada keluarga khususnya ibu "muda" (20-40 tahun) untuk meningkatkan subjective well-being. Direkomendasikan ke depan perlunya dilakukan penelitian untuk mengembangkan model pelatihan syukur (gratitude training model) berbasis penelitian pengembangan sekaligus melakukan uji efektivitas produk: apakah model pelatihan syukur yang dikembangkan mampu meningkatkan subjective well-being ibu "muda" (20-40 tahun).

\section{DAFTAR PUSTAKA}

Aiken, L.R. (2002). Human Development in Adulthood, New York. Kluwer Academic Publishers. 
Anjani, C. \& Suryanto (2006), Pola Penyesuaian Perkawinan pada Periode Awal, Insan, 8(3), 198-210.

Baumgardner, S.R. \& Crothers, M.K. (2010). Positive Psychology. River New Jersey: Pearson Prentice Hall.

Brooks, J.B. (2011). The Process of Parenting (eight edition). New York. McGraw-Hill Education.

Cavanaugh, J.C. \& Blanchard-Field, F. (2010). Adult Development and Aging, Sixth Edition, New York: Wadworth Cengange Learning.

Datu, J.A. (2014). Forgiveness, Gratitude and Subjective Well-Being Among Filipino Adolescents, Int. J. Adv. Counselling, 36, 262-273. DOI: 10.1007/ s10447-013-9205-9.

Diener, E., Lucas, R.E., Scollon, C.N. (2006). Beyond the Hedonic Treadmill. American Psychologist, 305-314.

Diener, E., Suh, E.M., Lucas, R.E. \& Smith, H.L., (1999). Subjective Well-Being; Three Decades of Progress. Psychological Bulletin, 125(2), 276-302.

Eggleston, E., Wong, E.L., Hardee, K., Irwanto, Poerwandari, E.K. \& Severy, L.J. (2001). Measuring Women's Psychological Well-Being in Indonesia. Women \& Health, 32(4), 17-32.

Emmons, R.A. \& McCulhough, M.E. (2003). Counting Blessing Versus Burdens: An Experimental Investigation of Gratitude and Subjective Well-Being in Daily Life. Journal of Personality and Social Psychology, 4(2), 377-389.

Emmons, R.A. \& McCulhough, M.E. (2004). The Psychology of gratitude. New York: Oxford University Press.

Emmons, R.A. \& Stern, R. (2013). Gratitude as Psychotherapeutic Intervention. Journal of Clinical Psychology: In Session, 69(8), 846-855.

Fredrickson, B.L. \& Joiner, T. (2002). Positive Emotions Trigger Upward Spirals Toward Emotional Well-Being. Psychological Science, 13(2), 172-175.

Fredrickson, B.L. (2003). The Value of Positive Emotions. American Scientist, 91, 330-335.

Fredrickson, B.L. (2004). The Broaden and Build Theory of Positive Emotions. The Royal Society, 1367-1377. 
Froh, J.J., Emmons, R.A., Huebner, E.S., Fan, J., Bono, G., \& Watkins, P. (2011). Measuring Gratitude in Youth; Assessing the Psychometric Properties of adult Gratitude Scales in Children and Adolescents. Psychological Assessment, 23(2), 311-324.

Froh, J.J., Yurkewicz, C. \& Kashdan, T.B. (2009). Gratitude and Subjective WellBeing ini Early Adolescence: Examining Gender Differences. Journal of Adolescence, 32, 633-650.

Hlava, P. \& Elfers, J. (2014). The Lived Experience of Gratitude. Journal of Humanistic Psychology, 54(4), 434-455.

Hlava, P., Elfers, J., \& Offringa, R. (2014). A Transcendent View of Gratitude: The Transpersonal Gratitude Scale. International Journal of Transpersonal Studies, 33(1), 1-14.

Martinez, M.L.M., Avia, M.D, Lloreda, M.I.H. (2010). The effect of Counting Blessing on Subjective Well-Being: A Gratitude Intervention in A Spanish Sample. The Spanish Journal of Psychology, 13(2), 886-896.

Musick, K., Meier, A., \& Flood, S. (2014). How Parents Fare: Mothers' and Fathers' Subjective Well-Being in Time with Children. California Center for Population Research. Los Angeles: University of California.

Papalia, D.E. \& Olds, S.W. (1986). Human Development, New York: McGrawHill Book Company.

Papalia, D.E., Olds, S.W. \& Feldman, R.D. (2009). Human Development (Perkembangan Manusia). Edisi 10, Buku 1\&2. Penerjemah Marswendy, B. Jakarta: Penerbit Salemba Humanika.

Peterson, C. \& Seligman, M.E.P. (2004). Character strength and virtue: Handbook of classification. Washington DC: American Psychological Association, New York: Oxford University Press.

Prastuti, E. (2016). Makna dan Sumber Subjective Well-Being Bagi Ibu Usia Dewasa Muda. Laporan Penelitian. Tidak Diterbitkan. Surabaya: Fakultas Psikologi Universitas Airlangga.

Prastuti, E., (2019). Rasa Syukur: Kunci Kebahagiaan dalam Keluarga, Jogjakarta: Penerbit Dee-Publish.

Prastuti, E., Tairas, M.M.W., \& Hartini, N. (2018). The Meaning and The Source of Mother's Happiness: An Explorative Study to Young Adult Mothers with Ages 20-40 Years Old, Makalah dipresentasikan pada pertemuan ICPHESOS, Surabaya: Fakultas Psikologi Universitas Airlangga. 
Prastuti, E., Tairas, M.M.W., \& Hartini, N. (2019). Model Kesejahteraan Subjektif Ibu dewasa Muda: Ditinjau dari Regulasi emosi, Mindfulness, dan Rasa Syukur, Disertasi, Surabaya: Fakultas Psikologi Universitas Airlangga.

Repetti, R.L. \& Wood, J. (1997). Effect of Daily Stress at Work on Mother's Interactions with Preschoolers. Journal of Family Psychology, 11(1), 90

Robinson, O.C., Wright, G.R.T., Smith, J.A. (2013). The Holistic Phase Model of Early Adult Crisis. Journal Adult Development, 20, 27-37.

Safaria, T. (2014). Forgiveness, Gratitude and Happiness Among College Students. International Journal of Public Health Science, 3(4), 241-245.

Seligman, M.E.P. (2010). Flourish: Positive Psychology and Positive Interventions, The Tanner Lectures on Human Values. The University of Michingan.

Seligman, M.E.P., \& Steen, T.A., Park, N., Peterson, C. (2005). Positive Psychology Progress Empirical Validation of Interventions. Tidsskrift for Norsk Psykologforening, 42, 874-884.

Setiono, K. (2011). Psikologi Keluarga. Bandung: PT. ALUMNI.

Tofangchi, M. (2013). Effectiveness of Gratitude Training on Happiness in Mother of Child with Mental Retardation, New York Science Journal, 6(12) 98-101.

Tugade, M.M., \& Fredrickson, B.L. (2007). Regulation of Positive Emotions: Emotion Regulation Strategies that Promote Resilience. Journal of Happiness Studies, 8, 311-333. DOI 10.1007/s10902-006-9015-4.

Wood, A.M., Froh, J.J., \& Geraghty, A.W.A. (2010). Gratitude and Well-Being: A Review and Theoretical Integration. Clinical Psychology Review DOI 10.1016/j.cpr.2010.03.005.

Wood, A.M., Maltby, J., Stewart, N., Linley, P.A. \& Joseph, S. (2008). A Social Cognitive Model of Trait and State Levels of Gratitude. Emotion. DOI: 10.1037/1528-3542.8.2.281.

Wood, A.M., Matby, J., Stewart, N., Joseph, S. (2007). Conceptualizing Gratitude and Appreciation as Unitary Personality Trait. Personality and Individual Differences, 44, 619-630. 